\title{
Kendali Radio Repeater Komunikasi Dua Meter Band Menggunakan Sistem Telekontrol Dual Tone Multi-Frequency
}

\author{
Aldi Rinaldi, Samuel Kristiyana*, Wiwik Handajadi \\ Departemen Teknik Elektro, Institut Sains \& Teknologi AKPRIND, Yogyakarta \\ *email: yanaista@akprind.acid
}

\begin{abstract}
Repeater strongly supports the use of radio communication equipment for communication. The location of the repeater is usually at a high altitude so that the repeater's radio wave beam is not blocked by anything. The repeater arrangement is done by going directly to the repeater location so it is very inefficient from the time and accommodation factor. Therefore, a study was conducted to control the radio repeater settings remotely in order to reduce the accommodation of repeater control by visiting the radio repeater location. Control of radio repeater settings uses DTMF (Dual Tone Multi-Frequency) technology which sends DTMF signals and then converts them to binary data to be processed into data that is used for repeater control such as turning on and off the radio, setting high and low power, and adjusting channels on the repeater. This system is also equipped with sending notifications in the form of SMS of the repeater operational conditions or settings. The research resulted in a remote control system based on DTMF technology equipped with a GSM/GPRS SIM800L module which is used to connect a smartphone to the system and send repeater operational notifications after controlling the repeater setting function. By using Telkomsel provider, the resulting delay when sending orders is 0.5 seconds and the delay in receiving SMS notifications is 12.96 seconds. Meanwhile, using Indosat provider, the resulting delay when sending commands is 0.43 seconds and the delay in receiving SMS notifications is 10.57 seconds.
\end{abstract}

Keywords - communication, control, DTMF, repeater, SIM800L.

\section{Pendahuluan}

Radio 2-meter band adalah radio frekuensi yang memiliki panjang gelombang 2 meter yang berpusat di frekuensi $144 \mathrm{MHz}-150 \mathrm{MHz}$ yang didapatkan berdasarkan formulasi panjang gelombang $(\lambda)$. Jika terdapat objek yang lebih tinggi dari gelombang radio yang dipancarkan pada jarak antara dua stasiun seperti gedung dan pohon tinggi atau pegunungan maka dapat ditentukan bahwa pengiriman atau penerimaan gelombang akan terhambat. Maka dibangunlah RPU (Radio Pancar Ulang) atau repeater yang berfungsi untuk meneruskan gelombang frekuensi yang ditransmisikan dan memperkuatnya. Untuk mendapatkan pancaran gelombang radio yang baik maka lokasi setiap repeater berada pada tempat yang jauh dan dataran tinggi. Sehingga untuk saat ini harus mendatangi lokasi repeater secara langsung untuk mengendalikan atau mengatur repeater tersebut. Oleh karena itu, penelitian dilakukan dengan tujuan untuk membuat suatu sistem yang dapat mengendalikan atau mengoperasikan pengaturan repeater dari jarak jauh menggunakan teknologi DTMF (Dual Tone MultiFrequency)

DTMF merupakan metode pensinyalan yang digunakan untuk memutar nomor telepon pilihan oleh sebagian besar telepon [1]. Penelitian dengan judul aplikasi kontrol jarak jauh lampu dan pagar rumah dengan teknologi Dual Tone Multiple Frequency (DTMF) ini bertujuan untuk mengontrol lampu dan pagar rumah mereka dari jarak jauh kapanpun dan dimanapun menggunakan teknologi DTMF pada telepon sehingga kendala yang saat ini dihadapi yaitu pemborosan penggunaan listrik dan dampat buruk lainnya seperti korsleting listrik dapat dikurangi atau bahkan dihilangkan. Penelitian selanjutnya berjudul sensor robot pemadam api

Manuscript submitted 20 July 2021; revised 30 August 2021; accepted 31 August 2021.

Published 31 August 2021; http://dx.doi.org/10.28989/avitec.v3i2.1043 
dengan beberapa mode operasi berbasis teknologi DTMF, Bluetooth dan GSM yang bertujuan membuat robot pemadam api menggunakan mode operasi dengan pengembangan metode line following, kontrol autonomous, kontrol manual yang dikontrol dengan basis teknologi DTMF, Bluetooth dan GSM [2]. Hasil dari penelitian berikutnya yang berjudul home automation using DTMF decoding menghasilkan sistem yang menggunakan nada DTMF sebagai sinyal kontrol[3]. Sistem kendali yang menggunakan teknologi DTMF juga diterapkan pada penelitian yang berjudul prototipe sistem kendali pintu gerbang berbasis DTMF dan hasil rancangan prototipe sistem pengendali pintu gerbang berbasis DTMF telah berhasil dibuat dan dapat berjalan sesuai fungsinya dengan menggunakan DTMF sebagai sistem utama[4]. Pada penelitian yang berjudul Remote Controlling Of An Agricultural Pump System Based On The Dual Tone Multi-Frequency (DTMF) Technique juga memanfaatkan pensinyalan DTMF untuk mengontrol perpindahan beban listrik seperti pompa pertanian yang berada di daerah terpencil [5].

\section{Metode Penelitian}

Metode penelitian yang digunakan adalah metode penelitian empiris eksperimental. Metode penelitian empiris eksperimental dilakukan dengan melakukan perancangan dan pengujian alat yang nyata, sehingga mendapatkan data langsung dari perancangan alat tersebut.

\subsection{Perancangan Sistem}

Pada penelitian ini, proses yang dilaksanakan yaitu pembuatan hardware. Secara umum blok diagram sistem pada penelitian Kendali Radio Repeater Komunikasi Dua Meter Band Menggunakan Sistem Telekontrol Dual Tone Multi-Frequency dapat dilihat pada Gambar 1.

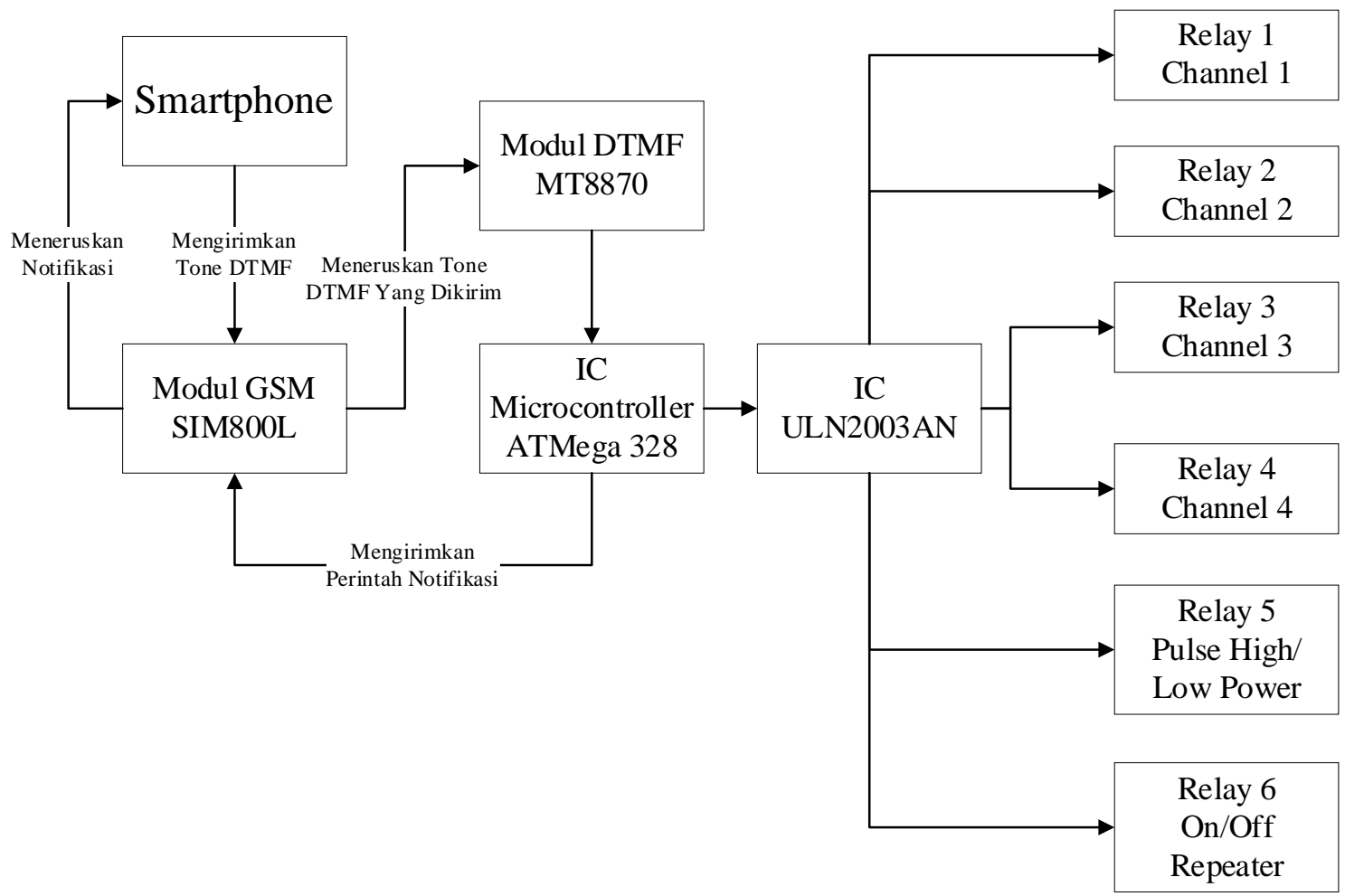

Gambar 1. Diagram Blok Sistem

Pada diagram blok di atas terdapat modul GSM/GPRS SIM800L yang difungsikan sebagai penghubung komunikasi smartphone dengan sistem untuk mengirimkan tone DTMF 
dari smartphone ke modul DTMF MT8870. Kemudian modul DTMF ini mengeluarkan BCD (Binary Code Decimal) yang dikirim ke mikrokontroler ATMega328 untuk diproses dan mengirimkan perintah ke relay untuk melakukan tindakan. Modul GSM SIM800L juga digunakan untuk mengirimkan notifikasi keadaan sistem ke smartphone atas perintah dari mikrokontroler.

Output dari atmega untuk logic 1 adalah 5 volt dan untuk logic 0 adalah 0 volt. Karena relay yang digunakan akan aktif atau berlogika 1 jika menerima input $L O W$, maka harus dilewatkan dahulu ke IC ULN2003A yaitu IC yang terdiri dari transistor-transistor darlington. Sehingga jika masukan pada input sebesar 5 volt, maka output dari IC tersebut adalah $L O W$ disetiap relay.

Selain itu terdapat 6 relay tambahan yaitu 4 relay yang digunakan untuk mengatur channel frekuensi. Sebuah relay lagi bertugas untuk mengatur high or low power radio repeater. Sedangkan sebuah relay lagi bertugas untuk mengaktifkan dan menonaktifkan radio repeater.

\subsection{Alat dan Bahan}

\subsubsection{DTMF Decoder Module MT8870}

DTMF adalah singkatan dari Dual Tone Multi-Frequency. Dual Tone Multiple Frequency (DTMF) adalah teknologi pengiriman nomor yang membentuk nomor telepon dan dikodekan menggunakan 2 nada yang dipilih dari 8 frekuensi yang telah ditentukan[6]. Modul yang ditunjukan pada Gambar 2 ini digunakan untuk mengirim sinyal menggunakan pita frekuensi suara melalui saluran telepon ke switching centers.

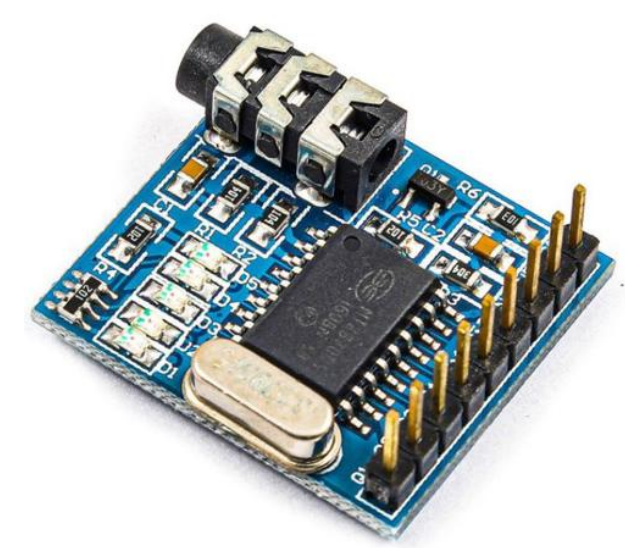

Gambar 2. DTMF Decoder Module MT8870

\subsubsection{Arduino Uno}

Sebagaimana ditunjukan pada Gambar 2, board Arduino Uno ini dilengkapi dengan USB connector yag memungkinkan untuk melakukan pemrograman dari PC/laptop. Board ini juga dapat diprogram menggunakan teknik In System Programming (ISP). Board ini dilengkapi dengan konverter USB-to-serial untuk memungkinkan kompatibilitas antara PC dengan sistem komunikasi serial yang terdapat di prosesor ATMega328 [7]. 


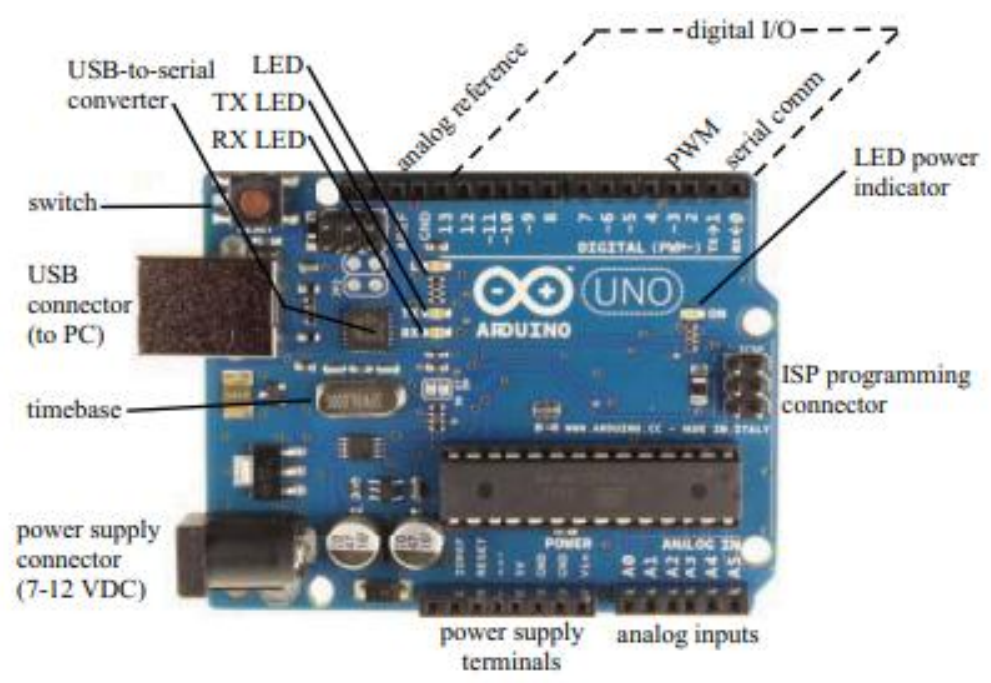

Gambar 3. Arduino Uno Layout

\subsubsection{IC ULN2003A}

ULN2003A (ditunjukan pada Gambar 3) adalah array transistor Darlington tegangan tinggi dan arus tinggi. Masing-masing terdiri dari tujuh pasang Darlington NPN yang menampilkan output tegangan tinggi dengan dioda penjepit katoda umum untuk mengalihkan beban induktif. Pengujian menggunakan bantuan sebuah IC ULN2003A biasanya sebagai penguat tegangan yang akan mengaktifkan relay $12 \mathrm{VDC}[11]$.

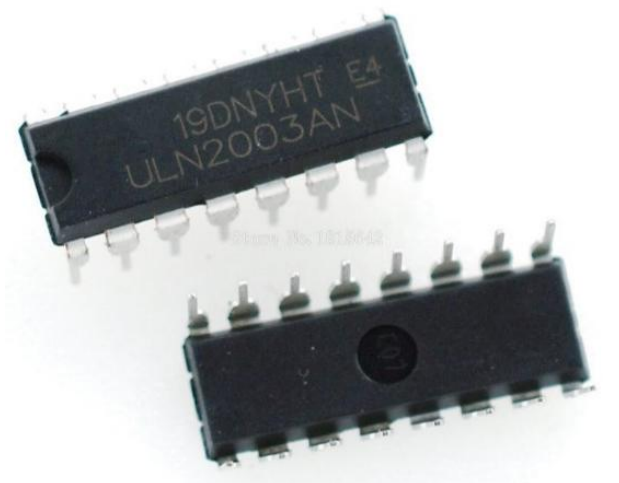

Gambar 4. IC ULN2003AN

\subsubsection{Modul GSM/GPRS SIM800L}

Modul GSM/GPRS SIM800L adalah modem GSM mini yang dapat diintegrasikan ke dalam sebagian besar proyek IoT. Modul yang ditunjukkan pada Gambar 5 ini dapat digunakan untuk menyelesaikan hampir semua hal yang dapat dilakukan oleh ponsel biasa seperti pesan teks SMS, membuat atau menerima panggilan telepon, menghubungkan ke internet melalui GPRS, TCP/IP dan lain-lain[8]. Selain itu, modul ini juga mendukung jaringan GSM/GPRS quad-band sehingga dapat bekerja hampir di mana saja. Pada penelitian ini, modul GSM digunakan untuk menerima panggilan telepon dan mengirimkan SMS notifikasi ke nomor tujuan. Cepat atau lambatnya pengiriman dipengaruhi oleh operator yang digunakan[9]. Perintah yang bisa diberikan oleh modem GSM/CDMA seperti mengirim dan menerima data berbasis GSM/GPRS atau mengirim dan menerima SMS adalah AT-Command[10]. 


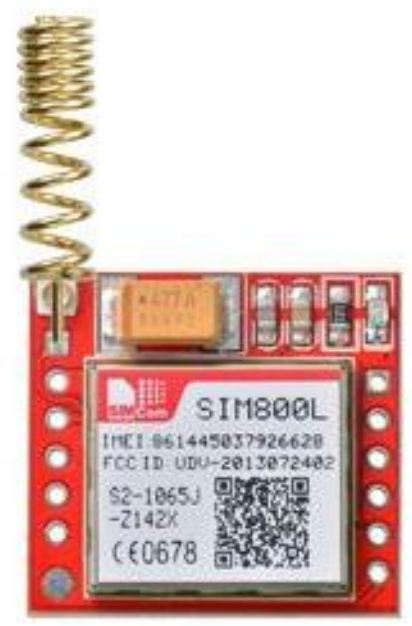

Gambar 5. Modul GSM/GPRS SIM800L

\section{Hasil dan Pembahasan}

\subsection{Hasil Penelitian}

Hasil dari penelitian yang ditunjukkan pada Gambar 6 adalah hardware yang berfungsi untuk melakukan pengendalian pengaturan repeater dari jarak jauh menggunakan jaringan provider berbasis pengkodean DTMF.

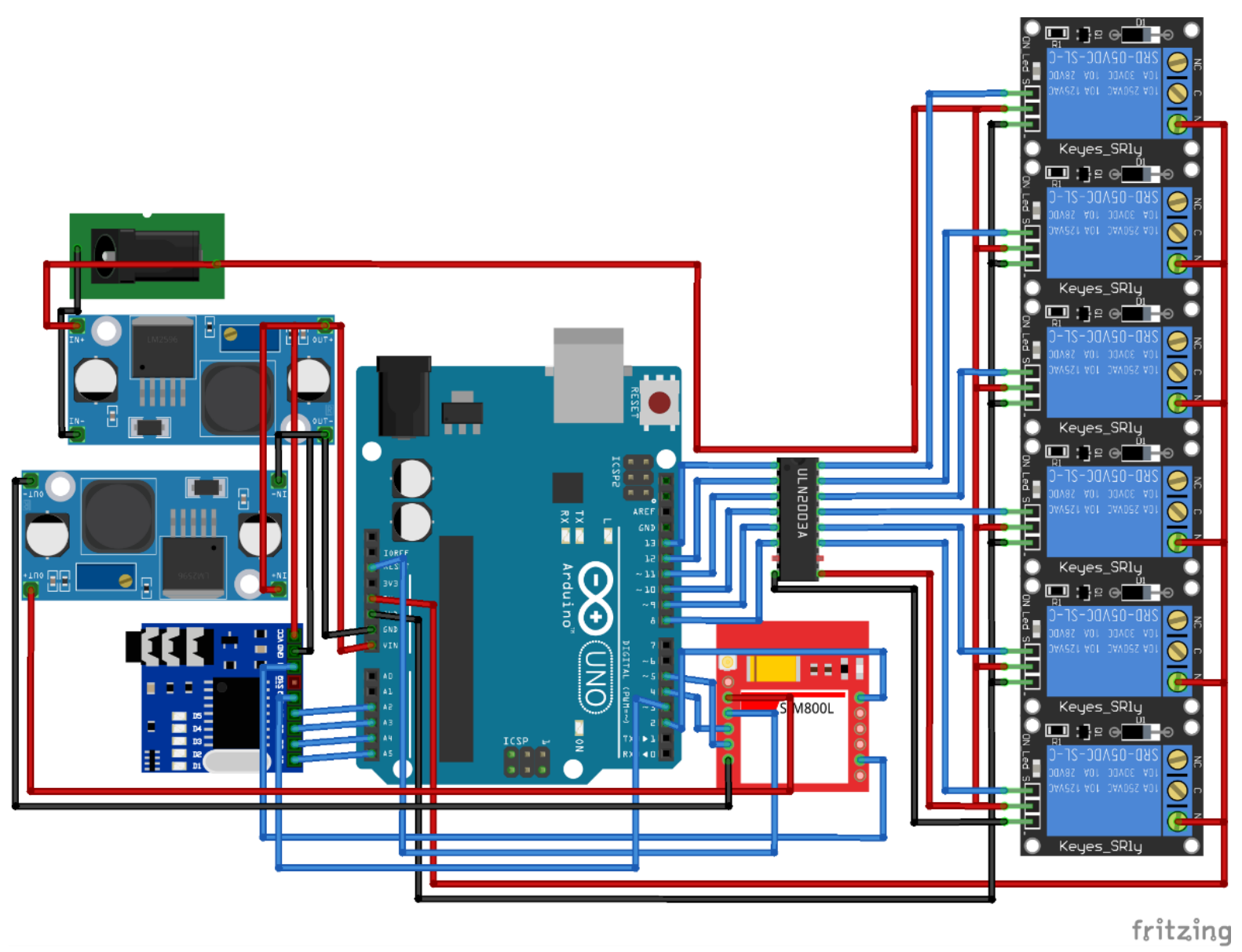

Gambar 6. Rangkaian Hardware 
Pada rangkaian yang ditunjukkan pada Gambar 6, Arduino Uno pada sistem ini berperan penting untuk memproses dan mengolah data input dan output dari modul komponen yang digunakan. Pada sistem ini terdapat 2 modul DC to DC stepdown yang input-nya terhubung $12 \mathrm{~V}$ dengan output yang dihasilkan adalah $5 \mathrm{~V}$ terhubung ke platform board Arduino Uno serta 3,7 V terhubung ke modul GSM/GPRS SIM800L.

Modul decoder DTMF MT8870 memiliki pin VCC, GND, IN, StD, StQ, dan Q1-Q4. Pin VCC dan GND terhubung pada pin VCC dan GND pada board Arduino Uno. Pin IN terhubung dengan pin SPK+ pada modul GSM/GPRS SIM800L. Pin StD terhubung pada pin D3 yang merupakan pin digital pada board Arduino Uno. Pin Q1-Q4 terhubung pada pin A2-A5 yang merupakan pin analog pada board Arduino Uno.

Modul GSM/GPRS SIM800L memiliki pin NET, VCC, RST, RxD, TxD, GND, RING, DTR, MIC-, MIC+, SPK-, SPK+. Pin NET terhubung pada antena modul SIM800L. Pin VCC dan GND terhubung pada pin VCC dan GND pada board Arduino Uno. Pin RST terhubung pada pin RESET pada board Arduino Uno. Pin RxD dan TxD terhubung pada pin D5 dan D4 pada board arduino yang digunakan untuk komunikasi serial. Pin RING terhubung pada pin D3 yang merupakan pin digital pada board Arduino Uno. Dan terakhir pin SPK+ terhubung dengan pin IN pada modul decoder DTMF MT8870 yang digunakan untuk meneruskan tone DTMF agar diubah menjadi binary code.

IC ULN2003AN memiliki kaki input, output, VCC dan GND. Kaki input IC terhubung pada pin D8-D13 yang merupakan pin digital board Arduino Uno. Kaki output IC terhubung dengan pin IN pada relay. Kaki VCC terhubung dengan 12V dan kaki GND terhubung dengan ground. Relay pada sistem ini berfungsi sebagai saklar elektronik pengaturan repeater.

\subsubsection{Pengujian Kehandalan Sistem}

Pengujian kehandalan sistem ini dilakukan untuk memastikan alat dapat berfungsi dengan baik mulai dari input dan output sehingga akan meminimalisir terjadinya error pada sistem yang dibuat. Data yang dihasilkan pada Tabel 1 sebagai berikut.

Tabel 1. Pengamatan Tegangan Sistem

\begin{tabular}{c|l|c}
\hline No & \multicolumn{1}{|c|}{ Jenis Tegangan } & Nilai (VDC) \\
\hline 1 & Tegangan catu daya sistem & 12,12 \\
\hline 2 & Tegangan output modul stepdown 12V to 5V & 5,06 \\
\hline 3 & Tegangan output modul stepdown 5V to 3,7V & 3,70 \\
\hline 4 & Tegangan input platform Arduino Uno & 5,06 \\
\hline 5 & Tegangan input modul GSM/GPRS SIM800L & 3,70 \\
\hline 6 & Tegangan input modul decoder DTMF MT8870 & 5,06 \\
\hline 7 & Tegangan output relay & 5,06 \\
\hline
\end{tabular}

\subsubsection{Pengujian Pengkodean DTMF}

Dari pengujian kode DTMF maka didapat data nilai biner yang dihasilkan oleh tone atau nada dari setiap angka yang dikirim. Biner yang dihasilkan ditampilkan menggunakan indikator LED. Data yang dihasilkan dapat dilihat pada Tabel 2. 
Tabel 2. Pengujian Pengkodean DTMF

\begin{tabular}{c|c|c|c|c|c|c}
\hline \multirow{2}{*}{$\begin{array}{c}\text { Digit } \\
\text { Angka }\end{array}$} & \multicolumn{2}{|c|}{ Tone Frequency } & \multicolumn{4}{c}{ Indikator Biner } \\
\cline { 2 - 7 } & $\begin{array}{c}\text { Low } \\
\text { Frequency }\end{array}$ & $\begin{array}{c}\text { High } \\
\text { Frequency }\end{array}$ & $\begin{array}{c}\text { LED } \\
\mathbf{4}\end{array}$ & $\begin{array}{c}\text { LED } \\
\mathbf{3}\end{array}$ & $\begin{array}{c}\text { LED } \\
\mathbf{2}\end{array}$ & $\begin{array}{c}\text { LED } \\
\mathbf{1}\end{array}$ \\
\hline 1 & $697 \mathrm{~Hz}$ & $1209 \mathrm{~Hz}$ & 0 & 0 & 0 & 1 \\
\hline 2 & $697 \mathrm{~Hz}$ & $1336 \mathrm{~Hz}$ & 0 & 0 & 1 & 0 \\
\hline 3 & $697 \mathrm{~Hz}$ & $1477 \mathrm{~Hz}$ & 0 & 0 & 1 & 1 \\
\hline 4 & $770 \mathrm{~Hz}$ & $1209 \mathrm{~Hz}$ & 0 & 1 & 0 & 0 \\
\hline 5 & $770 \mathrm{~Hz}$ & $1336 \mathrm{~Hz}$ & 0 & 1 & 0 & 1 \\
\hline 6 & $770 \mathrm{~Hz}$ & $1477 \mathrm{~Hz}$ & 0 & 1 & 1 & 0 \\
\hline 7 & $852 \mathrm{~Hz}$ & $1209 \mathrm{~Hz}$ & 0 & 1 & 1 & 1 \\
\hline 8 & $852 \mathrm{~Hz}$ & $1336 \mathrm{~Hz}$ & 1 & 0 & 0 & 0 \\
\hline 9 & $852 \mathrm{~Hz}$ & $1477 \mathrm{~Hz}$ & 1 & 0 & 0 & 1 \\
\hline 0 & $941 \mathrm{~Hz}$ & $1336 \mathrm{~Hz}$ & 1 & 0 & 1 & 0 \\
\hline$*$ & $941 \mathrm{~Hz}$ & $1209 \mathrm{~Hz}$ & 1 & 0 & 1 & 1 \\
\hline$\#$ & $941 \mathrm{~Hz}$ & $1477 \mathrm{~Hz}$ & 1 & 1 & 0 & 0 \\
\hline
\end{tabular}

\subsubsection{Pengujian Kecepatan Pengiriman Data}

Pengujian kecepatan pengiriman data dilakukan untuk mengetahui Delay yang dihasilkan pada saat mengirimkan perintah ke perangkat keras. Pengamatan delay masingmasing pengaturan dilakukan menggunakan 2 provider dengan pengujian 10 kali percobaan. Data rata-rata setiap fungsi pengaturan yang dihasilkan dapat dilihat pada Tabel 3 dan Tabel 4 sebagai berikut.

Tabel 3. Rata-Rata Delay Pengiriman Perintah Fungsi Pengaturan Menggunakan Provider Telkomsel

\begin{tabular}{c|l|c|c}
\hline $\begin{array}{c}\text { Digit } \\
\text { Angka }\end{array}$ & \multicolumn{1}{|c|}{ Fungsi Pengaturan } & $\begin{array}{c}\text { Kondisi } \\
\text { Relay }\end{array}$ & $\begin{array}{c}\text { Waktu Tunda } \\
\text { (Delay) }\end{array}$ \\
\hline 1 & Channel 1 & ON & 0,48 detik \\
\hline 2 & Channel 2 & ON & 0,45 detik \\
\hline 3 & Channel 3 & ON & 0,54 detik \\
\hline 4 & Channel 4 & ON & 0,55 detik \\
\hline 5 & High / Low Power & ON / OFF & 0,54 detik \\
\hline 6 & Mengaktifkan Sistem Repeater & ON & 0,52 detik \\
\hline 7 & Menonaktifkan Sistem Repeater & OFF & 0,48 detik \\
\hline
\end{tabular}


Tabel 4. Rata-Rata Delay Pengiriman Perintah Fungsi Pengaturan Menggunakan Provider Indosat

\begin{tabular}{c|l|c|c}
\hline $\begin{array}{c}\text { Digit } \\
\text { Angka }\end{array}$ & \multicolumn{1}{|c|}{ Fungsi Pengaturan } & $\begin{array}{c}\text { Kondisi } \\
\text { Relay }\end{array}$ & $\begin{array}{c}\text { Waktu Tunda } \\
\text { (Delay) }\end{array}$ \\
\hline 1 & Channel 1 & ON & 0,44 detik \\
\hline 2 & Channel 2 & ON & 0,43 detik \\
\hline 3 & Channel 3 & ON & 0,41 detik \\
\hline 4 & Channel 4 & ON & 0,42 detik \\
\hline 5 & High / Low Power & ON / OFF & 0,45 detik \\
\hline 6 & Mengaktifkan Sistem Repeater & ON & 0,42 detik \\
\hline 7 & Menonaktifkan Sistem Repeater & OFF & 0,41 detik \\
\hline
\end{tabular}

\subsubsection{Pengujian Kecepatan Pengiriman SMS}

Pengujian kecepatan pengiriman notifikasi sistem ini dilakukan untuk mengetahui waktu tunda (delay) yang dihasilkan pada saat pengiriman notifikasi dari sistem ke smartphone. Pengamatan delay masing-masing pengaturan dilakukan menggunakan 2 provider dengan pengujian 10 kali percobaan. Data yang dihasilkan pada Tabel 5 dan Tabel 6 sebagai berikut berikut:

Tabel 5. Rata-rata Waktu Tunda (Delay) Notifikasi SMS Menggunakan Provider Telkomsel

\begin{tabular}{c|l|c}
\hline $\begin{array}{c}\text { Digit } \\
\text { Angka }\end{array}$ & Fungsi Pengaturan & $\begin{array}{c}\text { Waktu Tunda } \\
\text { (Delay) }\end{array}$ \\
\hline 1 & Channel 1 & 10,00 detik \\
\hline 2 & Channel 2 & 10,18 detik \\
\hline 3 & Channel 3 & 14,79 detik \\
\hline 4 & Channel 4 & 14,46 detik \\
\hline 6 & Mengaktifkan Sistem & 14,20 detik \\
\hline 7 & Menonaktifkan Sistem & 14,13 detik \\
\hline
\end{tabular}

Tabel 6. Rata-rata Waktu Tunda (Delay) Notifikasi SMS Menggunakan Provider Indosat

\begin{tabular}{c|l|c}
\hline $\begin{array}{c}\text { Digit } \\
\text { Angka }\end{array}$ & \multicolumn{1}{|c|}{ Fungsi Pengaturan } & $\begin{array}{c}\text { Waktu Tunda } \\
\text { (Delay) }\end{array}$ \\
\hline 1 & Channel 1 & 10,23 detik \\
\hline 2 & Channel 2 & 9,98 detik \\
\hline 3 & Channel 3 & 10,78 detik \\
\hline 4 & Channel 4 & 10,59 detik \\
\hline 6 & Mengaktifkan Sistem & 11,16 detik \\
\hline 7 & Menonaktifkan Sistem & 10,68 detik \\
\hline
\end{tabular}




\subsection{Pembahasan}

Secara umum sistem ini sudah dapat bekerja dengan baik, sistem sudah dapat melakukan berbagai macam fungsi pengaturan repeater seperti pengaturan channel 1-4, pengaturan fungsi high/low power repeater, serta pengaturan fungsi mengaktifkan dan menonaktifkan repeater melalui smartphone menggunakan sistem telekontrol DTMF. Hasil pengamatan kehandalan sistem sudah sesuai dengan yang diinginkan mulai dari nilai tegangan hingga fungsi dari setiap pengaturan. Faktor yang membuat sistem ini dapat bekerja dengan baik adalah supply tegangan catu daya yang memadai untuk mengaktifkan hardware dan jaringan provider yang bagus untuk melakukan pengendalian melalui smartphone. Data pengendalian fungsi pengaturan didapatkan melalui notifikasi berupa SMS yang dikirim oleh sistem.

Hasil pengamatan delay yang dihasilkan setiap fungsi pengaturan sangat kecil. Menggunakan provider Telkomsel didapatkan rata-rata delay pada saat pengiriman dari setiap fungsi pengaturan didapatkan sebesar 0,5 detik dan rata-rata delay penerimaan notifikasi dari setiap fungsi pengaturan sebesar 12,96 detik. Sedangkan menggunakan provider Indosat didapatkan rata-rata delay pada saat pengiriman dari setiap fungsi pengaturan didapatkan sebesar 0,43 detik dan rata-rata delay penerimaan notifikasi dari setiap fungsi pengaturan sebesar 10,57 detik. Berdasarkan data yang didapatkan, delay yang dihasilkan saat sistem menerima perintah dan mengirimkan notifikasi dipengaruhi oleh jaringan provider yang digunakan terhadap lokasi pengujian sistem. Dengan didapatkannya data ini maka pengaturan dapat dilakukan dari jarak jauh menggunakan panggilan telepon berbasis DTMF serta mendapatkan notifikasi kondisi sistem tanpa harus mendatangi lokasi repeater.

\section{Kesimpulan}

Pada hasil pengujian kehandalan sistem, nilai tegangan yang didapatkan sesuai dengan kebutuhan sistem dan pengujian kerja sistem didapatkan bahwa pengaturan yang dikendalikan pada sistem kendali ini meliputi kendali pengaturan channel 1-4, pengaturan high/low power, serta pengaturan mengaktifkan dan menonaktifkan sistem repeater dapat digunakan sesuai fungsinya. Sistem kendali repeater jarak jauh ini memanfaatkan teknologi DTMF. Pada hasil pengujian pengkodean DTMF, setiap digit angka menghasilkan fekuensi yang merupakan hasil penjumlahan high dan low frequency. Output dari DTMF adalah 4 bit biner yang ditampilkan pada indikator biner D0-D3. Sistem kendali repeater ini dilengkapi dengan modul GSM/GPRS SIM800L untuk menghubungkan smartphone ke sistem dan mengirimkan notifikasi operasional repeater setelah melakukan pengendalian pengaturan repeater. Dari hasil pengujian data yang didapatkan menggunakan provider Telkomsel rata-rata delay yang dihasilkan pengiriman perintah pengaturan dalah 0,5 detik dan rata-rata delay yang dihasilkan untuk menerima SMS notifikasi adalah 12,96 detik. Sedangkan dengan menggunakan provider Indosat, rata-rata delay yang dihasilkan pengiriman perintah pengaturan dalah 0,43 detik dan rata-rata delay yang dihasilkan untuk menerima SMS notifikasi adalah 10,57 detik.

\section{Ucapan Terima Kasih}

Penulis mengucapkan terimakasih atas peran serta dalam penelitian ini kepada Laboratorium Sensor dan Sistem Telekontrol Dept. Teknik Fisika Universitas Gadjah Mada serta Laboratorium Teknologi Komunikasi Dept. Teknik Elektro Institut Sains \& Teknologi AKPRIND Yogyakarta.

\section{Daftar Pustaka}

[1] Windarto, \& Ristianti, R. (2015). Aplikasi Kontrol Jarak Jauh Lampu Dan Pagar Rumah Dengan Teknologi Dual Tone Multi Frequency (DTMF). Seminar Nasional Informatika, 99-104. 
[2] Benny Suhendar, Ahmad Surahmat, T. D. F. (2020). Sensor Robot Pemadam Api Dengan Beberapa Mode Operasi Berbasis Teknologi Dtmf, Bluetooth dan GSM. SAINTEK: Jurnal Sains \& Teknologi, 4(2), 135-150.

[3] Harsh Taneja, Komal Bhagat (Mehta), Maansi Gupta, P. K. (2019). Home Automation Using DTMF Decoding. International Journal of Research and Analytical Reviews (IJRAR), 6(1), 184-187.

[4] Hendarto, D., \& Libriana, O. (2016). Prototipe Sistem Kendali Pintu Gerbang Berbasis DTMF (Dual Tune Multiple Frequency). Jurnal Teknik Elektro \& Sains, 3(1), 10-17.

[5] Getu, B. N., Hamad, N. A., \& Attia, H. A. (2015). Remote Controlling Of An Agricultural Pump System Based On The Dual Tone Multi-Frequency (DTMF) Technique. Journal of Engineering Science and Technology, 10(10), 1261-1274.

[6] Ahmad Rofiq Hakim, A. T. (2016). Pemanfaatan Teknik Coding Dual Tone Multiple Frequency (DTMF) Dan Telepon Seluler Pada Model Sistem Pintu Elektronik Di Jurusan Teknologi Informasi Politeknik Negeri Samarinda. Jurnal Sains Terapan Teknologi Informasi, 8(1), 931-940.

[7] Barrett, S. F. (2012). Arduino microcontroller: Processing for everyone. In Synthesis Lectures on Digital Circuits and Systems, 38.

[8] Artawan, M. D., Ngurah Gunawan, A. A., \& Sumadiyasa, M. (2018). Use Of Short Message Service (SMS) Based ATmega328 Microcontroller and SIM800L Modules as On / Off Control Electronic Equipments. Advances in Applied Physics, 6(1), 19-24.

[9] Moch Indra Samudera, Samuel Kristiyana, G. S. (2016). Telemetri Intensitas Cahaya Matahari Dan Tekanan Udara Sebagai Pendukung Mitigasi Bencana Dengan Iinformasi SMS Gateway. Jurnal Elektrikal, 3, 86-93.

[10] Dharma, I. P. L., Tansa, S., \& Nasibu, I. Z. (2019). Perancangan Alat Pengendali Pintu Air Sawah Otomatis dengan SIM8001 Berbasis Mikrokontroler Arduino Uno. Jurnal Teknik, 17(1), 40-56.

[11] Almanda, D., \& Yusuf, H. (2017). Perancangan Prototype Proteksi Arus Beban Lebih Pada Beban DC Menggunakan Mikrokontroller. Elektum : Jurnal Teknik Elektro, 14(2), 25-34. 